\title{
Towards a revision of the genus Periclimenes: resurrection of Ancylocaris Schenkel, 1902, and designation of three new genera (Crustacea, Decapoda, Palaemonidae)
}

\author{
Zdeněk Ďuriš', Ivona Horká \\ I Department of Biology and Ecology and Institute of Environmental Technologies, Faculty of Science, Univer- \\ sity of Ostrava, Chittussiho 10, CZ-710 00 Ostrava, Czech Republic \\ Corresponding author: Zdeněk Ďuriš (zdenek.duris@osu.cz) \\ Academic editor:S. De Grave | Received 4 December 2016 | Accepted 14 December 2016 | Published 17 January 2017 \\ http://zoobank.org/82CC88F8-88B0-49D4-90AF-1F9D02B1B444 \\ Citation: Duriš Z, Horká I (2017) Towards a revision of the genus Periclimenes: resurrection of Ancylocaris Schenkel, \\ 1902, and designation of three new genera (Crustacea, Decapoda, Palaemonidae). ZooKeys 646: 25-44. https://doi. \\ org/10.3897/zookeys.646.11397
}

\begin{abstract}
Based on recently published molecular phylogenies of Indo-West Pacific palaemonid shrimps and further morphological evidence, the systematic position of several species of the polyphyletic genus Periclimenes is revised. The generic name Ancylocaris Schenkel, 1902 is re-established for the anemone-associated $P$. brevicarpalis. Actinimenes gen. n., is proposed for the anemone-associated P. inornatus, P. ornatellus and $P$. ornatus, all of which have a subspatulate first pereiopod. Cristimenes gen. n., is designated for the echinoderm-associated species, $P$. commensalis, $P$. cristimanus, and $P$. zanzibaricus, all with a unique carpopropodal articulation of the second pereiopods. Rapimenes gen. $\mathbf{n}$. is established for the hydroid and antipatharian-associated P. brucei, P. granulimanus, and P. laevimanus, for which the long, slender and unequal second pereiopods and prehensile ambulatory propodi are the main synapomorphic characters.
\end{abstract}

\section{Keywords}

Ancylocaris, Actinimenes, Cristimenes, Periclimenes, Rapimenes, symbiotic shrimps 


\section{Introduction}

The apparently polyphyletic and highly diverse palaemonid shrimp genus Periclimenes O. G. Costa, 1844 (e.g. Bruce et al. 2005) has in recent decades undergone some splitting by the designation of new genera for several species groups, e.g. Exoclimenella Bruce, 1995, Periclimenella Bruce, 1995, Manipontonia Bruce, Okuno \& Li, 2005, Crinotonia Marin, 2006, Brucecaris Marin \& Chan, 2006, Unguicaris Marin \& Chan, 2006, Margitonia Bruce, 2007, Leptomenaeus Bruce, 2007, Rapipontonia Marin, 2009, and Ancylomenes Okuno \& Bruce, 2010. Equally, several synonymised genera were reestablished, e.g. Harpilius Dana, 1852, Urocaris Stimpson, 1860, Laomenes AH Clark, 1919 and Cuapetes AH Clark, 1919 (see Bruce 2004, 2007a, b, c, Okuno and Fujita 2007, Okuno 2009). However, the genus Periclimenes as presently delineated still represents a heterogeneous assemblage of taxa of unresolved systematic status.

Although several molecular studies were recently constructed (Kou et al. 2013, Gan et al. 2015, Horká et al. 2016) to examine intrageneric relationships of the genus Periclimenes, a full resolution has not been achieved yet, partly due to incomplete coverage of species diversity, partly due to the low basal support of some clades within the analysis. Excluding the species recently allocated to Echinopericlimenes Marin \& Chan, 2014 and Bathymenes Kou, Li \& Bruce, 2016, only about 25 species of Periclimenes are involved in the analyses representing about $20 \%$ from the almost 130 species presently in the genus.

Periclimenes is clearly a genus which will see a further, strong reduction of its species diversity in the future. The type species, $P$. amethysteus (Risso, 1827) is a member of a clade of four sea anemone associated species distributed in the Mediterranean Sea and neighbouring part of the eastern Atlantic Ocean. It seems quite probable that only those species, with perhaps a few allied Atlantic species, will remain in Periclimenes, while all other species are likely to require allocation to further new or indeed resurrected genera. As indicated from the phylogenetic reconstruction provided by Horká et al. (2016), this group of anemone shrimps may be related to the majority of other Atlantic Periclimenes species, including the western Atlantic anemone shrimps, as well as Atlantic and Indo-Pacific deep-water Periclimenes, Echinopericlimenes, Altopontonia Bruce, 1990, and Bathymenes species. As the systematic relationship of these taxa still remains poorly supported in the recent phylogenies, and due to the lack of inclusion of many other Atlantic taxa, the exact composition of Periclimenes (s.s.) thus remains unclear.

Nevertheless, it is evident from the phylogeny in Horká et al. (2016) that most Indo-West Pacific representatives of the genus (as currently defined) are unrelated to the Atlantic Periclimenes taxa as a whole, and some natural groups can easily be separated from the genus based on molecular and morphological support. This report is a contribution to a series of revisions of the genus, resurrecting a synonym and establishing three new genera for some species of Indo-West Pacific Periclimenes species.

Abbreviations: fcn, field collection number; MHNG, Muséum d'Histoire Naturelle, Geneve; MNHN, Muséum National d'Histoire Naturelle, Paris; MTQ, Museum of 
Tropical Queensland, Townsville; RMNH, Naturalis Biodiversity Centre (formerly Rijksmuseum van Natuurlijke Historie), Leiden; spm(s), specimen(s); sp./spp., species (single/plural); UO, University of Ostrava.

\section{Systematics}

\section{Superfamily Palaemonoidea Family Palaemonidae Rafinesque, 1815}

\section{Genus Ancylocaris Schenkel, 1902}

Type species. Ancylocaris brevicarpalis Schenkel, 1902, by monotypy.

Included species. Ancylocaris brevicarpalis Schenkel, 1902 (Figs 1, 3A, B).

Gender. Feminine.

Diagnosis. Subcylindrical body form. Carapace smooth; rostrum well developed, subequal to antennular peduncle and moderately high, dorsal margin convex, dentate, with first tooth postorbital, ventral margin convex, with 1-2 teeth on distal third of rostrum length. Inferior orbital angle produced, without reflected inner flange, supraorbital and epigastric teeth absent, antennal and hepatic teeth present. Fourth thoracic sternite with broad transverse ridge subdivided by deep narrow median incision. Pleon smooth, third tergite non-carinated or posteriorly produced, pleura 1-5 posteroventrally rounded; telson with 2 pairs of minute dorsal spines on distal third of telson length and 3 pairs of short posterior marginal spines. Ophthalmic somite without interocular process. Antennule and antenna as usual for the family; upper ramus of antennular flagellum biramous, with fused basal part; scaphocerite moderately broad, with small distolateral tooth falling short of anterior margin of lamina; carpocerite short. Eyes with small accessory pigment spot dorsally on corneal margin. Mandible without palp; molar and incisor processes normal. Maxilla with basal endite distinctly bilobed, coxal endite obsolete, scaphognathite normal; first maxilliped with endites fused, exopod well developed, with multiple terminal setae, caridean lobe normal, epipod feebly bilobed; second maxilliped with normal endopod, exopod as in first maxilliped, without caridean lobe, epipod small, simple, without podobranch; third maxilliped with slender endopod, ischiomerus fused or feebly separated from basis, exopod as in second maxilliped, coxa with semi-circular lateral plate, single arthrobranch present. First pereiopods slender, coxa with distomedial setose lobe, fingers of chelae elongate, with lateral cutting edges. Second pereiopods moderately stout, similar and subequal, chelae with fingers kept laterally; fingers subequal to palm, cutting edges with simple lamina and 2 low proximal teeth, carpo-propodal articulation simple, carpus much shorter than palm in adults, feebly cup-shaped. Ambulatory pereiopods slender, propodus without ventral spines, dactyli with minute or reduced distoventral tooth on stout corpus, unguis elongate, curved. Endopod of male first pleopod simple, elliptic, with 


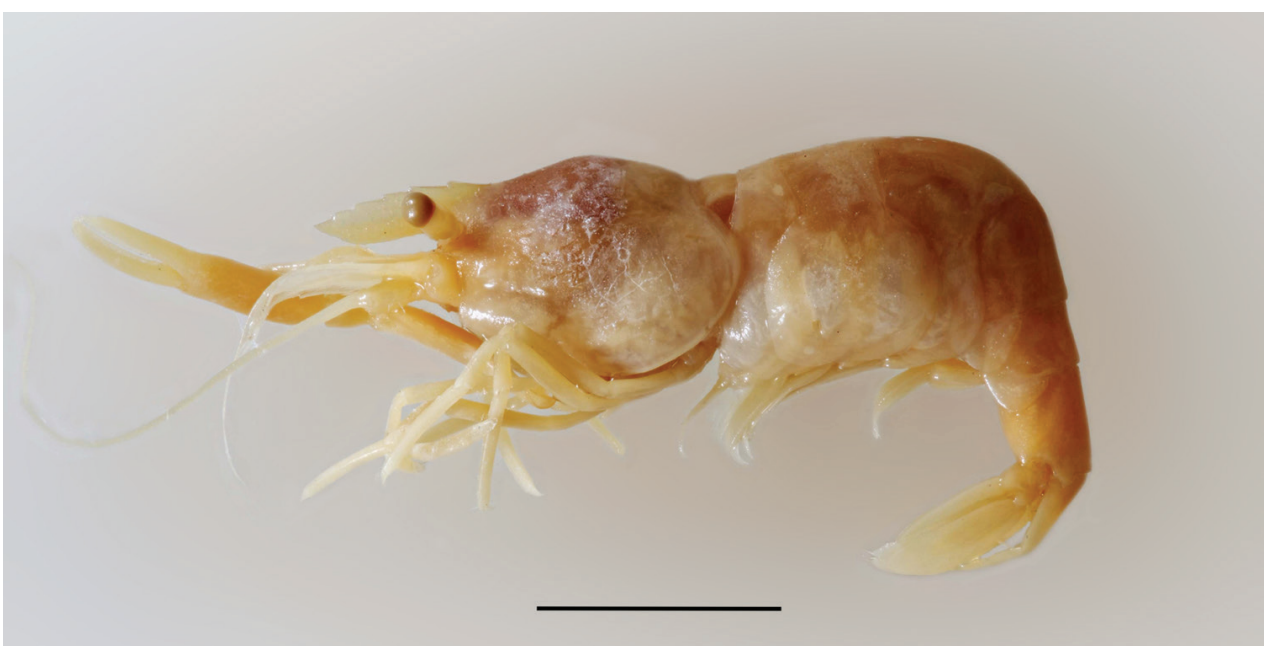

Figure I. Holotype of Palaemonella amboinensis Zehntner, 1894, adult female, MHNG (photo: L Monod; scale bar $5 \mathrm{~mm})$.

multiple spinules medioproximally and multiple pappose setae distally. Male second pleopod with appendix masculina slender, with several simple terminal and lateral setae. Uropods normal.

Figures (selected). Schenkel (1902: Pl. 13, fig. 21), Kemp (1922: figs 40-42, Pl. 6, fig. 8), Kubo (1940: figs 13-14), Miyake and Fujino (1968: fig. 4), Bruce (1978: fig. 6; 1979: Pl. 1, fig. A), Fransen (1989: fig. 1a-c).

Systematic position. Ancylocaris brevicarpalis (under the name Periclimenes brevicarpalis), together with P. inornatus Kemp, 1922, P. nevillei Bruce, 2010, P. ornatus Bruce, 1969, P. ornatellus Bruce, 1979, and P. albolineatus Bruce \& Coombes, 1997, were previously believed to be members of a "P. brevicarpalis" group (see Bruce and Svoboda 1983, Bruce and Coombes 1997, Bruce 2010) some of which are sea anemone associated species. On the contrary, Fransen (1989) stated that only three of those species, i.e. P. inornatus, $P$. ornatellus, and $P$. ornatus, are closely related to each other and comprise a "P. inornatus" group (see Actinimenes gen. n., below), rather than belong in the " $P$. brevicarpalis" group. The available comprehensive molecular phylogenies (Gan et al. 2015, Horká et al. 2016) show that at least $A$. brevicarpalis (under the name $P$. brevicarpalis) occupies a position away from the $P$. inornatus group.

While the species of the "P. inornatus" group share with Ancylocaris the general shape of the body, especially of the rostrum and the second pereiopods, they may easily be distinguished from $A$. brevicarpalis by the presence of deeply subspatulate chelae of the first pereiopod, but also by the more numerous proximal teeth on the fingers of the second pereiopod, as well as larger and more anteriorly placed dorsal telson spines (the first pair before mid-length). The propodal segment of the second maxilliped in A. brevicarpalis is broader than the dactylus and distomesially expanded, while subequally broad in the "P. inornatus" group (e.g. Kubo 1940, Bruce 1979). 
The sister taxon for Ancylocaris, as revealed by the analyses of Gan et al. (2015) and Horká et al. (2016), is actually a pair of Periclimenes species, the crinoid-associated $P$. affinis (Zehntner, 1894) and P. kallisto Bruce, 2008, which is symbiotic with antipatharian corals. The significant genetic distance of this pair however indicates that their position is most likely quite distant from Ancylocaris. Both those species show some resemblance to A. brevicarpalis in the size and position of the dorsal telson dentition, and in the distomedial coxal lobe and fingers on the first pereiopods. Periclimenes affinis also has a short carpocerite and a similar carpus of the second pereiopod, and similar male pleopod shape and setation. Periclimenes kallisto has feeble dentition of the fingers of the second pereiopod and the ambulatory dactyli with a minute distoventral tooth. These two species are more slender and smaller than A. brevicarpalis and bear a slender rostrum with obsolete ventral carina, unequal second pereiopods, ventrally spinulose ambulatory propodi, and the endopod of the male first pleopod has a distomedial lobe (Holthuis 1958, Bruce 1980, 2008a). A close affinity between these two species was suggested by Bruce (2008a), who highlighted a group of species of a similar morphology, additionally including P. canalinsulae Bruce \& Coombes, 1997, and P. jugalis Holthuis, 1952. Some other taxa, for instance P. novaffinis Bruce \& Coombes, 1997 , P. albolineatus and $P$. nevillei, may also belong to this group. The systematic relation of this assemblage as well as of each particular member to the genus Ancylocaris remains to be resolved.

Remarks. The earliest report on the present species was published by Zehntner in 1984. However, Holthuis (1952) places Palaemonella amboinensis Zehntner, 1894 into the synonymy of Ancylocaris brevicarpalis Schenkel, 1902 under the name Periclimenes brevicarpalis (Schenkel, 1902), as he considers the drawing of the scaphocerite and the antennular peduncle in Zehntner (1894) not to be entirely correctly drawn. After the examination of a photograph of the holotype (Fig. 1) kindly provided by L. Monod (MHNG) we fully concur with this position. Palaemonella amboinensis Zehntner (1894) should thus have priority over Periclimenes brevicarpalis (Schenkel, 1902); however as stated by Holthuis (1952) the latter name is preoccupied by Periclimenes amboinensis (De Man, 1888), originally described as Anchistia amboinensis De Man, 1888. For some time now both taxa are no longer considered congeneric, as Anchistia amboinensis De Man, 1888 was placed in the genus Laomenes AH Clark, 1919, resurrected for a group of crinoid dwelling species by Okuno and Fujita (2007). Conversely, Ancylocaris brevicarpalis Schenkel, 1902 was maintained in the genus Periclimenes up to now, although now returned to the resurrected genus Ancylocaris. This creates some ambiguity as to what is the correct name for the taxon currently known as Periclimenes brevicarpalis (Schenkel), a rather widespread, well-known and often photographed species.

Article 60.1 (ICZN 1999) specifies that a junior homonym must be rejected and replaced either by an available and potentially valid synonym or, for lack of such a name, by a new substitute name. We herein interpret Holthuis's (1952) action in proposing to use a junior synonym, Ancylocaris brevicarpalis Schenkel, 1902, for Palaemonella amboinensis Zehntner, 1894 as a "substitute name". In which case, Art. 59.3 specifies "that a junior secondary homonym replaced before 1961 is permanently invalid 
unless the substitute name is not in use and the relevant taxa are no longer considered congeneric, in which case the junior homonym is not to be rejected on grounds of that replacement". Clearly, the substitute name, Periclimenes brevicarpalis (Schenkel) is in widespread use, throughout the scientific literature as well as popular accounts, as it is one of the most photographed shrimp species. Even though both taxa have not been considered congeneric since the resurrection of the genus Ancylocaris makes Ancylocaris brevicarpalis Schenkel, 1902 the valid name for the species in question.

Distribution. The single species in the genus is widely distributed throughout the whole Indo-West Pacific, from South Africa and Red Sea to Japan and Polynesia.

Ecology. Ancylocaris brevicarpalis is obligatory associated with sea anemones (Cnidaria: Actiniaria) (cf. Fransen 1989, Müller 1993), although juveniles may also occur on alcyonarian and scleractinian corals.

\section{Actinimenes gen. n.}

http://zoobank.org/A1D1A9D6-406C-4EB3-B750-494A81EEAF9A

Type species. Periclimenes ornatus Bruce, 1969, by present designation.

Included species. Actinimenes inornatus (Kemp, 1922), comb. n. (Fig. 3C); A. ornatus (Bruce, 1969), comb. n. (Fig. 3D); and A. ornatellus (Bruce, 1979), comb. n.

Diagnosis. Carapace smooth; rostrum well developed, compressed, dorsal and ventral margins convex, with 7-10 dorsal teeth (posterior tooth behind orbits) and 0-2 ventral teeth, lateral carinae and orbit feebly developed, epigastric and supraorbital spines absent, inferior orbital angle usually produced, rounded, antennal tooth marginal, hepatic tooth close to level of latter. Pleon smooth, third segment not posteriorly produced, pleura rounded. Telson with two pairs of moderately large dorsal marginal spines situated on anterior and posterior thirds of telson length; three pairs of posterior spines, lateral spines smaller than dorsal spines. Eyes with globular cornea, small additional pigment spot dorsally on corneal margin. Antennule well developed. Antennal basicerite armed with lateral tooth; scaphocerite well developed, moderately broad, with distolateral tooth small, not reaching distal end of lamella. Mandible without palp, molar process robust, incisor process as usual for the family. Maxillula with bilobed palp, laciniae as usual for the family. Maxilla with simple palp, basal endite slender, deeply bilobed, coxal endite obsolete, scaphognathite moderately broad. First maxilliped with simple palp, basal endite fused with coxal endite, exopod with large caridean lobe, flagellum slender with several plumose distal setae, epipod feebly bilobed. Second maxilliped with normal endopod, propodus not produced distomesially, exopod similar to first maxilliped, without accessory lobe, coxa with oval epipod without podobranch. Third maxilliped with slender endopod, ischiomerus fused to basis, exopod as in second maxilliped, coxa with oval lateral plate, arthrobranch rudimentary or lacking. Fourth thoracic sternite with broad transverse ridge subdivided by median incision. First pereiopods moderately slender, chela with fingers subequal to palm, deeply subspatulate with entire cutting edges, coxa with setose distoventral lobe. 
Second pereiopods well developed, smooth, similar and equal, fingers with several small recurved teeth on proximal half, palm subcylindrical, longer than fingers, carpo-propodal articulation terminal, carpus much shorter than palm, merus unarmed, coxa without distoventral lobe. Ambulatory pereiopods moderately slender, propodus without ventral spines, dactyli with stout unarmed corpus, unguis elongate, curved. Endopod of male first pleopod simple, elliptic, feebly spinulose medioproximally, with several setulose setae distolaterally. Male second pleopod with appendix masculina slender, with several simple terminal and lateral setae. Uropods normal, exopod with small distolateral tooth and normal movable spine.

Etymology. From Actiniaria, the order of Anthozoa which comprises the host sea anemones for the genus, and Periclimenes to which genus the species previously belonged; gender masculine.

Figures (selected). Kemp (1922: figs 43-46), Bruce (1976: 10-11; 1979: figs 3B, 4-7, Pl. 1: fig. B-E; 1982: figs 11-12), Fransen (1989: figs 2-3).

Systematic position. Based on recent molecular studies (Gan et al. 2015, Horká et al. 2016), species of the genus Actinimenes gen. n. show a close phylogenetic relationship to two groups of taxa, Zenopontonia Bruce, 1975 and some other echinoderm-associated taxa on the one hand, and to the Periclimenes diversipes species group on the other hand. While the latter are also cnidarian associates, they are distinctly smaller species with more slender ambulatory pereiopods and dactyls, but mainly with very distinctive second pereiopods with both or at least one of the chelae of a specific subspatulate shape, with fingers generally longer than palm. Further, the species of the latter group share a similar shape of rostrum, and position of the carapacial teeth, subspatulate first pereiopod chela, short carpus of second pereiopods, simple ambulatory dactyli with elongate sharp unguis, and the shape and spinulation of the male pleopods (Bruce 1989).

Zenopontonia as well as other related echinoderm-associated taxa, such as $P$. colemani Bruce, 1975, and Lipkemenes lanipes (Kemp, 1922), are generally also very similar to Actinimenes by the position of antennal and hepatic teeth, an incised transverse ridge on the fourth thoracic sternite, the deeply subspatulate chelae of the first pereiopod, the shape of the chela of the second pereiopod and the very short carpus, and by the shape and spinulation of the male pleopods (Bruce 1989). These species however differ from Actinimenes spp. by a more down curved rostrum, more posteriorly situated and smaller dorsal telson spines, fine pectination on the fingers of the first pereiopod, and the ambulatory dactyli having small distoventral tooth on the corpus, sometimes also fully reduced (Marin 2012). Some mollusc- or ascidian-associated genera, e.g. Anchistus Borradaile, 1898, Paranchistus Holthuis, 1952, or Dasella Lebour, 1945, show some phylogenetic relationship to these echinoderm associated taxa (Gan et al. 2015, Horká et al. 2016), and thus more remotely also to Actinimenes gen. n. All species of these genera differ however from Actinimenes gen. n. by specialized biunguiculate ambulatory dactyli.

The three species of Actinimenes gen. n. were previously thought to be part of the 'Periclimenes brevicarpalis group' (Bruce and Svoboda 1983, Bruce 2010), although 
Fransen (1989) regarded them as comprising a 'Periclimenes inornatus group' of identical composition of the new genus (see also Remarks for Ancylocaris brevicarpalis comb. n., above).

Distribution. Widely distributed in the Indo-West Pacific from the Red Sea and Kenya to Japan, Marshall Islands, and Fiji.

Ecology. The species of the present genus are all obligate associates of sea anemones (Cnidaria: Actiniaria) (see Fransen 1989, Müller 1993).

\section{Key to species identification of Actinimenes gen. n.}

$1 \quad$ Fourth thoracic sternite produced anteriorly, bilobed, lobes abutting but separated by narrow deep incision; colouration: body with dense longitudinal lines of orange dots, pereiopods dark purple/red spotted.....

A. ornatus (Bruce, 1969), comb. n.

- $\quad$ Fourth thoracic sternite with U-shaped median incision; colouration: generally transparent except white band between eyes; adult females with white median band on bottom of thoracic and abdominal segments ...................2

2 Ambulatory dactyli with unguis proximo-ventrally smooth (adult females with white median band on thoracic and abdominal segments)

A. inornatus (Kemp, 1922), comb. n.

- $\quad$ Ambulatory dactyli with unguis proximo-ventrally serrated

A. ornatellus (Bruce, 1979), comb. n.

\section{Cristimenes gen. $\mathbf{n}$.}

http://zoobank.org/4A7068CC-CB18-4D6B-A9B0-FD518F4B3F19

Type species. Periclimenes (Cristiger) commensalis Borradaile, 1915, by present designation.

Included species. Cristimenes commensalis (Borradaile, 1915), comb. n. (Figs 2A, B, 3F); C. cristimanus (Bruce, 1965), comb. n. (Figs 2C, D, 3E); and C. zanzibaricus (Bruce, 1967), comb. n.

Diagnosis. Carapace smooth; rostrum well developed, subequal to antennular peduncle, compressed, usually with 5-7 low dorsal and 0-3 ventral teeth, lateral carinae with depressed supraorbital tooth, orbit feebly developed, epigastric tooth absent, inferior angle distinct, hepatic tooth close to antennal tooth and slightly lower positioned. Pleon smooth, fourth and fifth pleura posteroventrally angulate. Telson with two pairs of small dorsal spines on posterior half, and with three pairs of posterior spines. Eyes with globular cornea. Basal antennular segment with 2-3 acute distolateral teeth. Antenna with basicerite unarmed, scaphocerite moderately broad, with distolateral tooth small, not reaching distal level of lamina. Epistome with pair of lateral rounded tubercles. Mandible without palp, molar process robust, incisor process normal, with 3-4 terminal teeth; maxillula with bilobed palp, laciniae moderately broad; maxilla 


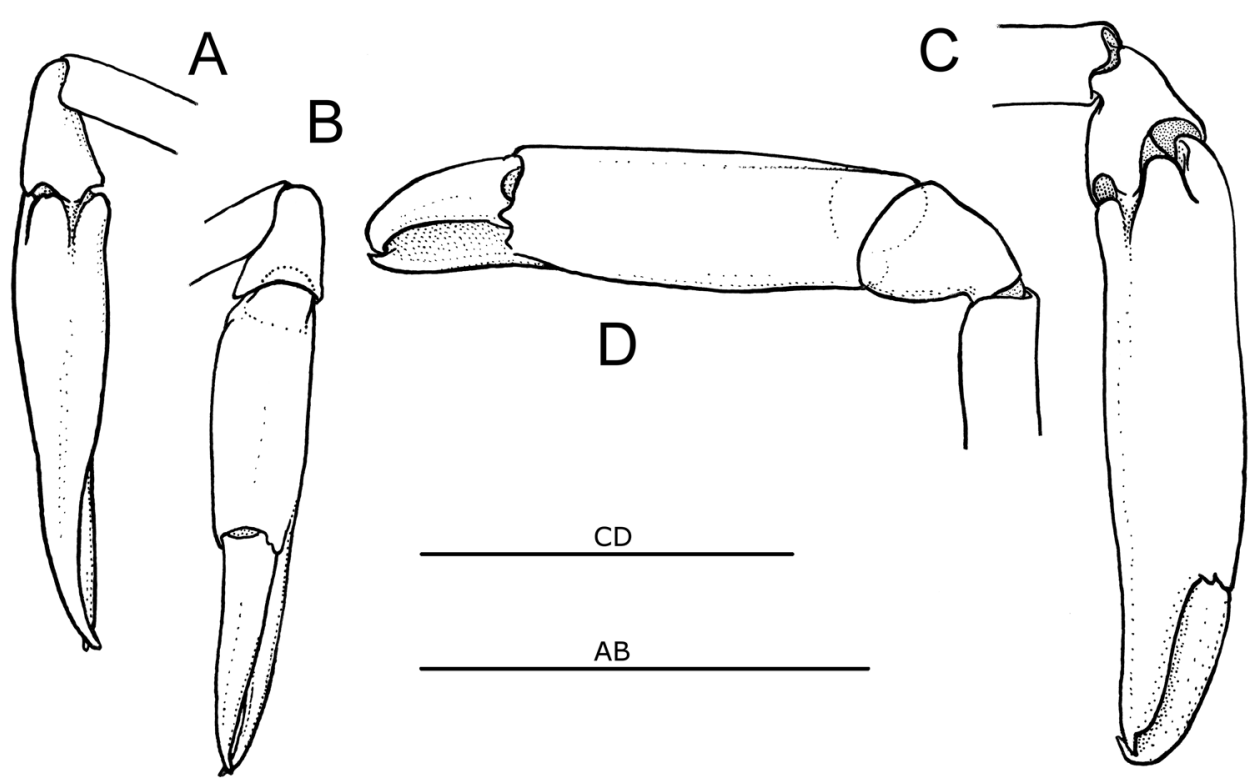

Figure 2. Second pereiopod of species of the genus Cristimanus gen. n. showing specific carpo-propodal articulation. A, B Cristimenes commensalis (Borradaile, 1915), comb. n., MTQ 33230, Lizard Island, Great Barrier Reef C, D Cristimenes cristimanus (Bruce, 1965), comb. n., UO 103-Vn08, Nhatrang Bay, Vietnam. (A, C medial aspect; B, D lateral aspect; scale bars $1 \mathrm{~mm}$ ).

with simple palp, basal endite slender, feebly bilobed or simple, coxal endite obsolete, scaphognathite moderately broad; first maxilliped with simple palp, basal and coxal endites fused, exopod with distinct caridean lobe, flagellum slender with 4 plumose distal setae, epipod bilobed; second maxilliped with normal endopod, propodus feebly produced medially, exopod similar to flagellum of first maxilliped, coxa with elongate epipod without podobranch, arthrobranch rudimentary; third maxilliped with slender endopod, ischiomerus distinct from basis, exopod as in second maxilliped, coxa with large subcircular lateral plate, arthrobranch rudimentary. Fourth thoracic sternite without median process. First pereiopods slender, chela with fingers tapering distally and feebly or distinctly subspatulate with entire cutting edges, coxa with obsolete distoventral lobe. Second pereiopods similar and subequal; cutting edges of fingers dentate or denticulate; palm elongate, subequal or longer than fingers, subterminally articulated to short cup-shaped carpus, with pair of proximal lobes fitting dorsally to carpal cavity; carpus and merus unarmed. Ambulatory pereiopods slender, dactyli bi- or triunguiculate (i.e. with or without dorsal spinule behind unguis), unguis long, almost subequal to corpus length; propodus with ventral spinules and tufts of soft setae. Uropodal exopod elongate, laterally straight, with small distolateral tooth with mobile spine medially.

Etymology. A combination of the subgeneric name Cristiger (see below) proposed by Borradaile, 1915 and Periclimenes in which genus the species were previously placed; 


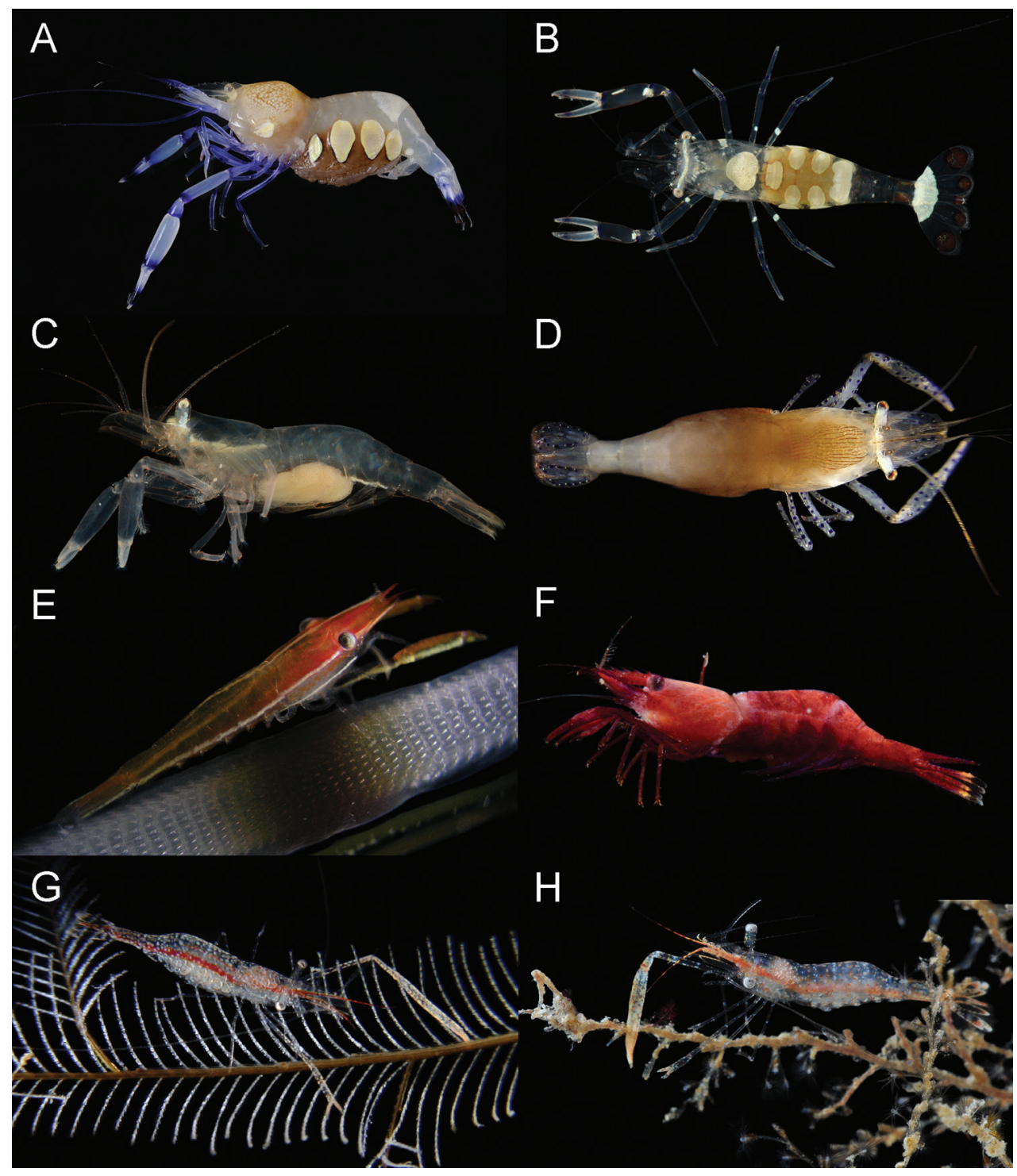

Figure 3. Examples of species from the genera reported in this study. A, B Ancylocaris brevicarpalis Schenkel, 1902: ovigerous females, MNHN-2014-558 and -156 (resp.), Kavieng, Papua New Guinea C Actinimenes inornatus (Kemp, 1922), comb. n., MNHN-IU-2014-315, with bopyrid parasite, Kavieng, Papua New Guinea D Actinimenes ornatus (Bruce, 1969), comb. n., ovigerous female, UO 80-Vn08, Nhatrang Bay, Vietnam E Cristimenes cristimanus (Bruce, 1965), comb. n., UO 103-Vn08, Nhatrang Bay, Vietnam F Cristimenes commensalis (Borradaile, 1915), comb. n., MTQ 33230, Lizard Island, Great Barrier Ree G Rapimenes laevimanus (Ďuriš, 2010), comb. n., ovigerous female holotype, RMNH D.53129, Nhatrang Bay, Vietnam H Rapimenes granulimanus (Bruce, 1978), comb. n., ovigerous female, MNHNIU-2013-509, Madang, Papua New Guinea. (Photos: A-G Z Ďuriš; H A Anker). 
gender masculine. As suggested by Holthuis (1993), the etymology of the name Cristiger $($ Latin $=$ crest-bearer) was possibly in reference to the convex upper margin of the rostrum in the type species (from crista $=$ crest, and gero $=$ to bear).

Figures (selected). Holthuis (1952: figs 18-19), Miyake and Fujino (1968: fig. 2e-g), Bruce (1965: figs 1-2; 1967: figs 26-29; 1982: fig. 2).

Systematic position. The present new genus is closely related to three crinoidassociated genera, Araiopontonia Fujino \& Miyake, 1970, Laomenes AH Clark, 1919, and Unguicaris Marin \& Chan, 2006. This was already suggested by Marin and Chan (2006), and later supported by phylogenetic analyses (Kou et al. 2013, Gan et al. 2015, Horká et al. 2016). All these echinoderm-associated shrimps have a well-developed, somewhat downturned rostrum, generally dentate both dorsally and ventrally; the epistome is with a pair of lateral lobes (low, rounded in Cristimenes gen. n. and Araiopontonia, but acutely produced in the remaining genera); similar and subequal second pereiopods, and ambulatory legs possessing a specific type of 'triunguiculate' dactylus with a long main unguis. Such dactyli are secondarily reduced to a more biunguiculate state by the reduction of the dorsal spinule in the echinoid-associated species C. cristimanus and C. zanzibaricus, as well as in the crinoid associated genus Laomenes. The depressed supraorbital teeth associated with the lateral rostral carina are a synapomorphic character for the group, however, secondarily lost in Unguicaris. Such a reduction of the supraorbital teeth and lateral carinae was illustrated in some specimens of C. commensalis by Monod (1976), or Bruce (1982).

Cristimenes gen. n., together with Araiopontonia, can be distinguished from the genera Laomenes and Unguicaris by the rounded lateral lobes on the epistome (vs. acute projecting lobes). The new genus differs from all the three genera by a 3-dentate mandibular incisor (vs. distally expanded, multidentate), and by the unique carpopropodal articulation of the second pereiopods, with the subterminal proximo-ventral articulation on the propodus leaving a distinctive posterior part of the propodus dorsally overhanging the articulation (Fig. 2). This lobe is deeply subdivided by a short but deep longitudinal groove into a pair of lobes which smoothly fit into the dorsal cavity of the short cup-shaped carpus when the propodus is extended anteriad. The proximal end of the propodus is then well hidden inside the carpus from dorsal view.

Range. Widely distributed throughout the whole Indo-West Pacific region.

Ecology. The genus Cristimenes comprises a single crinoid-associated species, $C$. commensalis comb. n., with the other two species, C. cristimanus comb. n., and $C$. zanzibaricus comb. n., living on echinoids (Echinodermata: Crinoidea, Echinoidea).

Remarks. The genus Cristimenes is established here for three species, with Periclimenes (Cristiger) commensalis as the type species. This species was designated as the type species of the subgenus Cristiger Borradaile, 1915 by Holthuis (1955) since the previous designation of Alpheus scriptus Risso, 1822 by Borradaile (1917) as the type was invalid. As pointed out by Holthuis $(1955,1993)$, the name Cristiger Borradaile is a junior homonym of Cristiger Gistel, 1848 (Hymenoptera), and thus not available to be used for the present genus. 


\section{Key to species identification of Cristimenes gen. $\mathbf{n}$.}

1 Ambulatory dactyli triunguiculate; associated with crinoids (basal antennular segment with 2-3 acute teeth distolaterally; first pereiopod fingers simple, subequal to palm; second pereiopods with cutting edges of fingers dentate proximally and denticulate distally)

C. commensalis (Borradaile, 1915), comb. $\mathrm{n}$.

- $\quad$ Ambulatory dactyli biunguiculate; associated with echinoids

2

2 Palm and dactylus of first pereiopod strongly compressed, palm tuberculate dorsally, dactylus carinate medially; second pereiopods with cutting edges of fingers dentate throughout; basal antennular segment with 3 acute teeth distolaterally C. cristimanus (Bruce, 1965), comb. $\mathrm{n}$.

- $\quad$ Palm and dactylus of first pereiopod normal, smooth dorsally, uncarinate; second pereiopods with cutting edges of fingers dentate proximally and denticulate distally; basal antennular segment with rounded lobe and 2 acute teeth distolaterally..... C. zanzibaricus (Bruce, 1967), comb. n.

\section{Rapimenes gen. $\mathbf{n}$.}

http://zoobank.org/5157C46E-9EC0-4D4A-A34E-CBA986D443A9

Type species. Periclimenes granulimanus Bruce, 1978, by present designation.

Included species. Rapimenes brucei (Ďuriš, 1990), comb. n.; $R$. granulimanus (Bruce, 1978), comb. n. (Fig. 3H); and R. laevimanus (Ďuriš, 2010), comb. n. (Fig. 3G).

Material examined. In addition to the type series (Duriš 2010), the following specimens were subsequently examined: $\boldsymbol{R}$. granulimanus -6 spms, (MNHNIU-2013-10931), 1 spm. (IU-2013-11097), 2 spms (IU-2013-11077), Papua Niugini Expedition 2012, Madang Lagoon, Papua New Guinea, Dec. 2012, coll. Z Durišs. - R. laevimanus - 3 spms (UO-Jp2012), Nago-city, Okinawa, Japan, 26³3,6'N, $127^{\circ} 57.6^{\prime} \mathrm{E}, 10 \mathrm{May} 2012$, depth $30 \mathrm{~m}$, on sea pen cf. Stylatula sp. [Pennatulacea]; coll.: N Sirakawa \& Y Yamada, lgt. R Minemizu.—1 spm. SW Taiwan, coll. C-W Lin (fcn 20130202-08).

Diagnosis. Medium sized shrimps. Carapace smooth, with antennal and hepatic teeth; epigastric tooth lacking or, if present, clearly separated from them; hepatic tooth subequal and situated posteriorly of antennal tooth and slightly below. Rostrum slender, dorsal lamina bearing 6-10 teeth, ventral lamina obsolete, with 1-2 subterminal teeth. Inferior orbital angle produced, rounded. Pleon smooth, pleura posteroventrally rounded; telson slender, tapering distally, with 1-2 pairs of small dorsal spines and three pairs of posterior marginal spines. Ophthalmic somite without interocular process. Antennula and antenna normal, scaphocerite 3-4 times longer than broad. Eye with globular cornea and small accessory pigment spot, stalk distinctly longer than corneal diameter. Mandible without palp, incisor and molar processes 
stout. Maxillula with bilobed palp, upper and lower laciniae well developed. Maxilla with slender palp, well developed scaphognathite, distal (basal) endite bilobed; proximal (coxal) endite lacking. First maxilliped with simple palp, basal endite broad, coxal endite feebly demarcated, exopod well developed, caridean lobe normal, epipod distally bilobed. Second maxilliped with normal endopod and exopod, epipod small, simple, without podobranch. Third maxilliped with slender segments, ischiomerus and basis fused; exopod well developed, coxa with rounded lateral plate, single small arthrobranch present. Fourth thoracic sternites without special structures. First pereiopods slender, fingers narrow, simple, with dense tufts of long setae on sides, coxa with or without distoventral setose process, basis unarmed. Second pereiopods long and slender, distinctly unequal in length; major pereiopod overreaching scaphocerite by distal part of merus in adults; fingers simple, cutting edges entire or with 1-2 feebly developed teeth on proximal third of minor chela, and with $2-4$ obtuse proximal teeth on major chela fingers; major pereiopod with palm 2.5-5 times longer than fingers. Ambulatory pereiopods slender, propodus with prehensile structure of long straight distoventral spines arranged to $2-5$ pairs, spines longer than distal propodal depth; dactyli slender and curved, simple, or with distinct or minute distoventral tooth. Endopod of first male pleopod with angulate apex and distinct medial lobe; second male pleopod with appendix masculina with 3 terminal serrated setae and 2 lateral setae. Uropods normal; distolateral angle of exopod with small tooth and movable spine medially.

Etymology. Combination of rapina, Latin for claw, to point on the prehensile structures on the ambulatory legs, and the name of the genus Periclimenes Costa, 1844, from which the new genus is separated; gender masculine.

Figures (selected). Bruce (1978: figs 16-19), Ďuriš (1990: figs 1-2; 2010: figs 1-8).

Systematic position. Based on the recent molecular phylogeny in Horká et al. (2016), the therein included two species of Rapimenes gen. n. are closely related to the genus Phycomenes Bruce, 2008, and to a pair of further Periclimenes spp., i.e. P. affinis, and P. kallisto, positioned near to A. brevicarpalis comb. n. From Phycomenes, the species of the genus Rapimenes gen. n., can be easily distinguished by their larger size, distinctly unequal second pereiopods, prehensile ambulatory legs, and lack of a triangular process on the fourth thoracic sternum (see Bruce 2008b, Duriš 2010). Morphologically, the new genus (i.e. the previous "P. granulimanus group") is phylogenetically close to the "P. obscurus group", as already indicated by Eilbracht and Fransen (2015) who also listed the characters distinguishing all species of those two groups. Included in the "P. obscurus group" are some species which show distinct similarities to Rapimenes, such as P. macrorhynchia Eilbracht \& Fransen, 2015, P. nomadophila Berggren, 1994, and $P$. tonga Bruce, 1988 (the latter synonymized with $P$. granulimanus by Marin 2012, but regarded as valid by Eilbracht and Fransen 2015), particularly in the shape and proportions of the pereiopods and rostrum. These species have biunguiculate walking dactyli, sternal thoracic ridges, and distinct setose coxal lobe on the first pereiopod, i.e. the characters typical for the "P. obscurus group". The ambulatory dactyli vary in Rapimenes spp. from simple to bearing a minute additional 
tooth; the latter is true for $R$. brucei, new comb., for which a coxal setose lobe also was reported (Duriš 1990). It is thus possible that both species groups represent a common evolutionary clade which inner diversity is still to be resolved.

Distribution. Madagascar; Maldive Islands; Indonesia; Vietnam and Taiwan, South China Sea; Japan; Heron Island, Great Barrier Reef, Australia.

Ecology. The species of the present genus have been recorded as associated with antipatharians, hydroids, pennatularians, and scyphozoans (Cnidaria) (Bruce 1978, 1988, Duriš 1990, 2010, Minemizu 2013, Eilbracht and Fransen 2015).

Remarks. The generic name Rapimenes was used as a nomen nudum by Marin (2009: 15) in reference to the then undescribed species Periclimenes laevimanus Duriš (2010), as "Rapimenes laevimanus Duriš \& Petrusek (in press)". The name is herein validly reinstated for the genus, indeed now containing Rapimenes laevimanus.

Key to species identification of Rapimenes gen. n. (modified from Ďuriš 2010).

$1 \quad$ Major second pereiopod extremely long and slender, overreaching scaphocerite by proximal merus, carpus longer than both chela or merus; walking dactyli feebly biunguiculate with small distoventral tooth on corpus, propodi with long spines arranged to 4 distoventral pairs.

R. brucei (Ďuriš, 1990), comb. n.

- $\quad$ Second pereiopods unequal, slender, at least overreaching scaphocerite by distal merus, carpus subequal or distinctly shorter than both chela or merus; walking dactyli simple or with rudimentary distoventral tooth, propodi with 1-3 single proximal spines in addition to 2-4 distoventral pairs of long spines .2

2 Major second pereiopod with palm granulate; minor second chela with 1-2 teeth on cutting edges ................R. granulimanus (Bruce, 1978), comb. n. Major second pereiopod with palm smooth; minor second chela with cutting edges entir

R. laevimanus (Ďuriš, 2010), comb. n.

\section{Acknowledgements}

Additional specimens were kindly provided for examination by Ryo Minemizu (Shimizu, Japan), and Chia-Wei Lin (National Museum of Marine Biology and Aquarium, Kenting, Taiwan), or collected during the Papua Niugini Expedition 2012 (part of Our Planet Reviewed) organized jointly by the MNHN, Pro Natura International, the Institut de Recherche pour le Développement, and the University of Papua New Guinea (PI - P Bouchet, S Samadi, and C Payri); funded by the Total Foundation, Prince Albert II of Monaco Foundation, Foundation EDF, Stavros Niarchos Foundation, and Entrepose Contracting; supported by the Divine Word University, permit delivered by the Papua New Guinea Department of Environment and Conservation. John Hollier 
and Lionel Monod (Natural History Museum, Geneva) are acknowledged for kind assistance with photographs of 'Palaemonella amboinensis' holotype.

Illustrative photos were obtained, or figures were prepared from specimens collected during the authors' trips to Vietnam, and during: (1) CReefs Lizard Island Expedition 2010, a part of the CReefs Australia - a partnership between the Australian Institute of Marine Science, BHP Billiton, the Census of Marine Life, and the Great Barrier Reef Foundation project (PI - J Caley and S Smith, AIMS, Townsville); (2) the Kavieng Lagoon Biodiversity Survey, 2014 (PI - P Bouchet and J Kinch) - a part of the 'Our Planet Reviewed' expedition organised jointly by MNHN, Paris, Pro-Natura International and Institut de Recherche pour le Développement, with support from Papua New Guinea's National Fisheries Authority. The organisers acknowledge supporting funding from the Total Foundation, Laboratoire d'Excellence Diversités Biologiques et Culturelles (LabEx BCDiv, ANR-10-LABX-0003-BCDiv), Programme Investissement d'Avenir (ANR-11-IDEX-0004-02), Fonds Pacifique, and CNRS' Institut Ecologie et Environnement.

Sammy De Grave (Oxford University Museum of Natural History, Oxford), Charles HJM Fransen (Naturalis Biodiversity Centre, Leiden), and Junji Okuno (Natural History Museum and Institute, Chiba) are acknowledged for reading the manuscript of the present study and for their kind proposals for its improvement, and Arthur Anker (Museum of Zoology, University of São Paulo, Brazil) for kindly providing a colour photograph. This study was supported by the Ministry of Education, Youth and Sports of the Czech Republic in the 'National Feasibility Program I', project LO1208 'TEWEP'.

\section{References}

Borradaile LA (1898) On some Crustaceans from the South Pacific. Part III, Macrura. Proceedings of the Zoological Society of London 1898: 63-95, Pls. 63-65. https://doi. org/10.1111/j.1096-3642.1898.tb03166.x/abstract

Borradaile LA (1915) Notes on Carides. The Annals and Magazine of Natural History, Ser. 8: 205-213. http://biostor.org/reference/58779

Borradaile LA (1917) On the Pontoniinae. The Percy Sladen Trust Expedition to the Indian Ocean in 1905, under the leadership of Mr. J. Stanley Gardiner, M.A. No. VIII. Transactions of the Linnean Society of London, $2^{\text {nd }}$ Series, Zoology 323-396, Pls 52-57. https:// doi.org/10.1111/j.1096-3642.1917.tb00470.x/abstract

Bruce AJ (1965) Notes on Indo-Pacific Pontoniinae, X. Periclimenes cristimanus sp. nov., a new pontoniid shrimp from Singapore. The Annals and Magazine of Natural History, Ser. 13: 487-493 https://doi.org/10.1080/00222936508651602

Bruce AJ (1967) Notes on some Indo-Pacific Pontoniinae III-IX. Descriptions of some new genera and species from the western Indian Ocean and the South China Sea. Zoologische Verhandelingen 87: 1-73. http://dare.uva.nl/cgi/arno/show.cgi?fid=148937 
Bruce AJ (1969) Preliminary descriptions of sixteen new species of the genus Periclimenes Costa, 1844 (Crustacea, Decapoda Natantia, Pontoniinae). Zoologische Mededelingen 43: 253-278. http://research.nhm.org/publications/referenceinfo.html?refid=24778

Bruce AJ (1975) Periclimenes colemani sp. nov., a new shrimp associate of a rare sea urchin from Heron Island, Queensland (Decapoda Natantia, Pontoniinae). Records of the Australian Museum 29: 486-502. https://doi.org/10.3853/j.0067-1975.29.1975.213

Bruce AJ (1976) A report on some pontoniid shrimps collected from the Seychelle Islands by the F.R.V. Manihine, 1972, with a review of the Seychelles pontoniid shrimp fauna. Zoological Journal of the Linnean Society 59: 89-153. https://doi.org/10.1111/j.1096-3642.1976. tb01012.x

Bruce AJ (1978) A report on a collection of pontoniine shrimps from Madagascar and adjacent seas. Zoological Journal of the Linnean Society 62: 205-290. https://oi.org/10.1111/ j.1096-3642.1978.tb01039.x

Bruce AJ (1979) A report on a small collection of pontoniine shrimps from Eniwetok Atoll. Crustaceana, Suppl. 5: 209-230. https://www.jstor.org/stable/25027504?seq=1\#page_ scan_tab_contents

Bruce AJ (1980) On some Pontoniine shrimps from Noumea, New Caledonia. Cahiers de l'Indo-Pacifique 2: 1-39. http://research.nhm.org/pdfs/24867/24867.pdf

Bruce AJ (1982) The pontoniine shrimp fauna of Hong Kong. In: Morton BS, Tseng CK (Eds) Proceedings of the 1st International Marine Biology Workshop: The marine flora and fauna of Hong Kong and southern China, Hong Kong, 1980. Hong Kong University Press, Hong Kong, 233-284. http://www.reefbase.org/resource_center/publication/pub_20467.aspx

Bruce AJ (1988) Periclimenes tonga sp. nov., a commensal shrimp associated with a scyphozoan host from Tonga (Crustacea: Decapoda: Palaemonidae). Micronesica 21: 23-32. https:// decapoda.nhm.org/pdfs/24923/24923.pdf

Bruce AJ (1989) Periclimenes gonioporae sp. nov. (Crustacea: Decapoda: Palaemonidae), a new coelenterate-associated shrimp. The Beagle, Records of the Northern Territory Museum of Arts and Sciences 6: 149-156. https://search.informit.com.au/documentSummary;dn=94 2059688801559; res=IELHSS

Bruce AJ (1990) Crustacea Decapoda: Deep-sea palaemonoid shrimps from New Caledonian waters. In: Crosnier A (Ed.) Résultats des Campagnes MUSORSTOM, vol. 6. Mémoires du Muséum national d'Histoire naturelle (A) Zoologie 145: 149-215.

Bruce AJ (1995) A synopsis of the Indo-West Pacific genera of the Pontoniinae (Crustacea: Decapoda: Pontoniinae). Theses Zoologicae 25: 1-172. https:/www.koeltz.com/product. aspx?pid $=164428$

Bruce AJ (2004) A partial revision of the genus Periclimenes Costa, 1844 (Crustacea: Decapoda: Palaemonidae). Zootaxa 582: 1-26. https://doi.org/10.11646/zootaxa.582.1.1

Bruce AJ (2007a) Leptomenaeus gen. nov., a new name for Leptomenes Bruce, 2006 (Crustacea: Decapoda: Pontoniinae). Cahiers de Biologie Marine 48: 411-412. http://application.sbroscoff.fr/cbm/pdf/307270841

Bruce AJ (2007b) A re-definition of the genus Periclimenes Costa, 1844 and the designation of a new genus Margitonia (Crustacea: Decapoda: Pontoniinae). Cahiers de Biologie Marine 48: 403-406. http://application.sb-roscoff.fr/cbm/pdf/1236834077 
Bruce AJ (2007c) Re-examination of Borradaile's Urocaris longicaudata specimens from the 1905 J.S. Gardiner Collection (Crustacea: Decapoda: Pontoniinae). Zootaxa 1644: 5157. https://doi.org/10.11646/zootaxa.3905.1.3

Bruce AJ (2008a) A new pontoniine shrimp from the Great Barrier Reef (Crustacea. Decapoda. Palaemonidae). Memoirs of the Queensland Museum 52: 89-98. http://www.qm.qld.gov. $\mathrm{au} /$ /media/Documents/QM/About+Us/Publications/Memoirs+-+Nature/N52-2/52-2bruce.pdf

Bruce AJ (2008b) Phycomenes zostericola gen. nov., sp. nov., a new pontoniine shrimp (Crustacea: Decapoda: Palaemonidae) from Moreton Bay, Queensland. In: Davie PJF, Phillips JA (Eds) Proceedings of the Thirteenth International Marine Biological Workshop, The Marine Fauna and Flora of Moreton Bay, Queensland. Memoirs of the Queensland Museum - Nature 54: 219-232. http://www.qm.qld.gov.au/_/media/Documents/QM/About+Us/Publications/ Memoirs+-+Nature/N54-1/n-54-1-bruce.pdf

Bruce AJ (2010) Periclimenes nevillei sp. nov. (Crustacea: Decapoda: Pontoniinae) from Vanuatu. Zootaxa 2510: 45-54. http://www.mapress.com/j/zt/article/view/8665

Bruce AJ, Coombes KE (1997) An annotated check-list of the caridean shrimps (Crustacea: Decapoda) of Darwin Harbour, with descriptions of three new species of Periclimenes (Palaemonidae: Pontoniinae). In: Hanley JR, Caswell G, Megirian D, Larson HK (Eds) Proceedings of the Sixth International marine biological workshop. The marine fauna and flora of Darwin Harbour, Northern Territory, Australia. Museums and Arts Galleries of the Northern Territory and the Australian Marine Sciences Association, Darwin, 301-337. http://trove.nla.gov.au/work/23282966?selectedversion=NBD24568168

Bruce AJ, Okuno J, Li X (2005) Manipontonia gen. nov., a new pontoniine shrimp genus for Periclimenes psamathe (De Man) (Crustacea: Decapoda: Palaemonidae). Zootaxa 926: 1-11. https://doi.org/10.11646/zootaxa.926.1.1

Bruce AJ, Svoboda A (1983) Observations upon some pontoniine shrimps from Aqaba, Jordan. Zoologische Verhandelingen 205: 1-44. http://www.repository.naturalis.nl/document/148926

Clark AH (1919) Some necessary changes in crustacean nomenclature. Proceedings of the Biological Society of Washington 32: 199. https://ia600201.us.archive.org/21/items/biostor-101746/biostor-101746.pdf

Costa OG (1844) Su due nuovi generi di Crostacei decapodi macrouri. Annali delle Accademia degli Aspiranti Naturalisti, Napoli 2: 285-292. http://research.nhm.org/publications/referenceinfo.html? refid $=11531$

Dana JD (1852) Conspectus Crustaceorum \&c. Conspectus of the Crustacea of the Exploring Expedition under Capt. C. Wilkes, U.S.N. Macroura. Proceedings of the Academy of Natural Sciences of Philadelphia 1852: 10-29. https://doi.org/10.5962/bhl.title.53615

Duriš Z (1990) Two new species of the palaemonid shrimp genus Periclimenes from the Maldive waters (Crustacea, Decapoda, Palaemonidae). Acta Societatis Zoologicae Bohemoslovacae 54: 1-8. https://decapoda.nhm.org/pdfs/25417/25417.pdf

Duriš Z (2010) Periclimenes laevimanus sp. nov. from Vietnam, with a review of the Periclimenes granulimanus species group (Crustacea: Decapoda: Palaemonidae: Pontoniinae). In: De Grave S, Fransen CHJM (Eds) Contributions to shrimp taxonomy. Zootaxa 2372: 106-125. http://www.mapress.com/zootaxa/2010/f/z02372p125f.pdf 
Eilbracht J, Fransen CHJM (2015) Periclimenes macrorhynchia sp. nov., a new hydrozoan-associated pontoniine shrimp (Crustacea, Decapoda, Palaemonidae) from North East Kalimantan, Indonesia. Zootaxa 3994: 377-395. https://doi.org/10.11646/zootaxa.3994.3.3

Fujino T, Miyake S (1970) Araiopontonia odontorhyncha gen. et sp. nov., a new shrimp from the Ruykyu Islands, Japan (Decapoda, Palaemonidae, Pontoniinae). Ohmu. Occasional papers of Zoological Laboratory, Faculty of Agriculture, Kyushu University, Fukuoka, Japan 3: $1-10$.

Fransen CHJM (1989) Notes on caridean shrimps collected during the Snellius-II expedition. I. Associates of Anthozoa. Netherlands Journal of Sea Research 23: 131-147. https://doi. org/10.1016/0077-7579(89)90008-2

Gan ZB, Li X, Chan T-Y, Chu KH, Kou Q (2015) Phylogeny of Indo-West Pacific pontoniine shrimps (Crustacea: Decapoda: Caridea) based on multilocus analysis. Journal of Zoological Systematics and Evolutionary Research 53: 282-290. https://doi.org/10.1111/jzs.12108

Gistel JNFX (1848) Naturgeschichte des Tierreichs, für höhere Schulen. Stuttgart, i-xvi, 1-216, Pls 1-32. https://doi.org/10.5962/bhl.title.97235

Holthuis LB (1952) The Decapoda of the Siboga Expedition. Part XI. The Palaemonidae collected by the Siboga and Snellius Expeditions with remarks on other species II. Subfamily Pontoniinae. Siboga Expeditie 39a10: 1-253.

Holthuis LB (1955) The recent genera of the caridean and stenopodidean shrimps (class Crustacea, order Decapoda, supersection Natantia) with keys for their determination. Zoologische Verhandelingen 26: 1-157. http://www.repository.naturalis.nl/document/149086

Holthuis LB (1958) Crustacea Decapoda from the northern Red Sea (Gulf of Aqaba and Sinai Peninsula). I. Macrura. Bulletin of the Sea Fisheries Research Station, Haifa 17: 1-40. http://www.repository.naturalis.nl/document/149213

Holthuis LB (1993) The recent genera of the caridean and stenopodidean shrimps (Crustacea, Decapoda) with an appendix on the order Amphionidacea. Fransen CHJM, van Achterberg C (Eds) Nationaal Natuurhistorisch Museum, Leiden, 157 pp. https://www.bibliotheek.nl/catalogus/titel.110627318.html

Horká I, De Grave S, Fransen CHJM, Petrusek A, Ďuriš Z (2016) Multiple host switching events shape the evolution of symbiotic palaemonid shrimps (Crustacea: Decapoda). Scientific Reports 6: 26486. https://doi.org/10.1038/srep26486

ICZN (1999) International code of zoological nomenclature, $4^{\text {th }}$ edition: adopted by the International Union of biological Sciences. The International Trust for Zoological Nomenclature, London. http://www.iczn.org/iczn/index.jsp

Kemp S (1922) Notes on Crustacea Decapoda in the Indian Museum, XV. Pontoniinae. Records of the Indian Museum 24: 113-288, Plates 1-9. http://www.biodiversitylibrary.org/ part/146043\#/summary

Kou Q, Li X-Z, Chan T-Y, Chu KH, Huang H, Gan Z (2013) Phylogenetic relationships among genera of the Periclimenes complex (Crustacea: Decapoda: Pontoniinae) based on mitochondrial and nuclear DNA. Molecular Phylogenetics and Evolution 68: 14-22. https://doi.org/10.1016/j.ympev.2013.03.010

Kou Q, Li X-Z, Bruce AJ (2016) Designation of a new genus Bathymenes for the deep-sea pontoniine shrimps of the 'Periclimenes alcocki species group' (Decapoda, Caridea, Palaemoni- 
dae), with a checklist of the species assigned to the genus. Chinese Journal of Oceanology and Limnology 33: 1-7. https://doi.org/10.1007/s00343-015-4359-4

Kubo I (1940) A new shrimp, Harpilius imperialis. Journal of the Imperial Fisheries Institute, Tokyo 34: 1-4.

Lebour MV (1945) Alteration in the name Dasia as a decapod genus. Proceedings of the Zoological Society of London 114: 279. https://decapoda.nhm.org/cgi-bin/mason.cgi/references/referenceinfo.html?refid $=26056$

Man JG de (1888) Bericht über die von Herrn Dr. J. Brock im indischen Archipel gesammelten Decapoden und Stomatopoden. Archiv für Naturgeschichte 53(3): 289-600, Pls 11-22a. https://doi.org/10.5962/bhl.part.4747

Marin I (2006) Description of Crinotonia anastasiae, new genus, a new crinoid associated pontoniine shrimp (Crustacea: Caridea) from Nha Trang Bay, Vietnam, with inclusion of Periclimenes attenuatus Bruce, 1971, in the new genus. The Raffles Bulletin of Zoology 54: 321-340. http://lkcnhm.nus.edu.sg/nus/pdf/PUBLICATION/Raffles\%20Bulletin\%20 of\%20Zoology/Past\%20Volumes/RBZ\%2054(2)/54rbz321-340.pdf

Marin I (2009) A review of the pontoniine shrimp genus Rapipontonia Marin, 2007 (Decapoda: Caridea: Palaemonidae), with the description of a new species from the Indo-West Pacific. Zootaxa 2289: 1-17. http://www.mapress.com/j/zt/article/view/7295

Marin I (2012) New records and associations of pontoniine shrimps (Crustacea: Decapoda: Caridea: Palaemonidae: Pontoniinae) from the Nhatrang Bay, Vietnam; with taxonomic remarks on some species from the Indo-West Pacific region. In: Britayev TA, Pavlov DS (Eds) Benthic fauna of the Bay of Nhatrang, Southern Vietnam 2. KMK Scientific Press, Moscow, 345-405.

Marin I, Chan T-Y (2006) Two new genera and a new species of crinoid-associated pontoniine shrimps (Decapoda: Caridea: Palaemonidae). Journal of Crustacean Biology 26: 524-539. https://doi.org/10.1651/S-2705.1

Marin I, Chan T-Y (2014) Deep water echinoid-associated pontoniine shrimp "Periclimenes hertwigi Balss, 1913” species group (Crustacea: Decapoda: Caridea: Palaemonidae): species review, description of a new genus and species from Philippines. Zootaxa 3835: 301-324. https://doi.org/10.11646/zootaxa.3835.3.1

Minemizu R (2013) Coral Reef Shrimps of Indo-West Pacific. Bun-Ichi Sogoshuppan, Co. Ltd., Tokyo, 145 pp. [In Japanese]

Miyake S, Fujino T (1968) Pontoniid shrimps from the Palau Islands (Crustacea, Decapoda, Palaemonidae). Journal of the Faculty of Agriculture, Kyushu University 14: 399-431. http://decapoda.nhm.org/pdfs/26215/26215.pdf

Monod T (1976) Sur une nouvelle collection de crustacés décapodes de Nouméa (NouvelleCalédonie). Cahiers du Pacifique 19: 133-152.

Müller H-G (1993) Catalogue of Indo-West Pacific pontoniine shrimps. H.-G. Müller, Wetzlar. http://www.vliz.be/imisdocs/publications/17544.pdf

Okuno J (2009) Cuapetes Clark, 1919, a senior synonym of Kemponia Bruce, 2004 (Crustacea: Decapoda: Palaemonidae). Zootaxa 2028: 67-68. http:/www.mapress.com/j/zt/article/ view/6014 
Okuno J, Bruce AJ (2010) Designation of Ancylomenes gen. nov., for the 'Periclimenes aesopius species group' (Crustacea: Decapoda: Palaemonidae), with the description of a new species and a checklist of congeneric species. In: De Grave S, Fransen CHJM (Eds) Contributions to shrimp taxonomy. Zootaxa 2372: 85-105. http://www.mapress.com/j/zt/article/view/7764

OkunoJ, FujitaY(2007) Resurrection of thegenus LaomenesA.H.Clark, 1919(Decapoda, Caridea, Palaemonidae). Crustaceana 80: 113-124. https://doi.org/10.1163/156854007779696514

Rafinesque CS (1815) Analyse de la nature ou tableau de l'univers et des corps organises. Palerme, 224 pp. https://doi.org/10.5962/bhl.title.106607

Risso A (1822) Sur quelques nouveaux Crustacés observés dans la mer de Nice. Journal de Physique, de Chimie et d'Histoire Naturelle 95: 242-248.

Risso A (1827) Histoire naturelle des principales productions de l'Europe Méridionale et particulièrement de celles des environs de Nice et des Alpes Maritimes, 5. Levrault F-G, Paris, i-vii, 1-403, Pls 1-10. https://doi.org/10.5962/bhl.title.58984

Schenkel E (1902) Beitrag zur Kenntnis der Dekapodenfauna von Celebes. Verhandlungen der Naturforschenden Gesellschaft in Basel 13: 485-585, Pls 7-13. https://decapoda.nhm. org/pdfs/26505/26505.pdf

Stimpson W (1860) Prodromus descriptionis animalium evertebratorum, quae in Expeditione as Oceanum Pacificum Septentrionalem, a Republic Federata missa, Cadwaladore Ringgold et Johanne Rodgers Ducibus, observavit et descripsit. Pars VIII, Crustacea Macrura. Proceedings of the Academy of Natural Sciences of Philadelphia 1860: 22-47 [pp. 91-116 on separate]. https://doi.org/10.5962/bhl.title.51447

Zehntner L (1894) Crustacés de l'Archipel Malais.Voyage de MM. M. Bedot et C. Pictet dans l'Archipel Malais. Revue Suisse de Zoologie et Annales du Musée d'Histoire Naturelle de Genève 2: 135-214, Pls 7-9. https://doi.org/10.5962/bhl.part.75134 